\title{
JURISDICTION OF THE EUROPEAN COURT OF HUMAN RIGHTS IN THE BALTIC STATES' CASES
}

\begin{abstract}
The Baltic States - Estonia, Lithuania and Latvia - are democratic states of law that respect human rights. As members of the Council of Europe, they implemented into domestic law the Convention on the Protection of $\mathrm{Hu}-$ man Rights and Fundamental Freedoms (known as the European Convention on Human Rights) - an international document for the universal protection of human rights adopted by the Council of Europe. The aim of the paper is to analyze whether and to what extent did Estonian, Lithuanian and Latvian citizens file individual complaints to the European Court of Human Rights over the past thirteen years (2006-2018). The paper is to answer the question if the Baltic Sates' systems of human rights protection are effective. One of the indicators of effectiveness is the number of complaints brought from the Baltic States to the ECtHR in relation to the number of inhabitants and also in comparison with the total number of complaints from the 47 member states of the Council of Europe as whole. The analysis will cover statistics on the number of judgments in Estonian, Lithuanian and Latvian cases before the Court in Strasbourg issued between 2006 and 2018. This will be helpful in determining the degree and the type of violations by the Baltic States of the human rights protected by the European Convention on Human Rights.
\end{abstract}

Keywords: Baltic States, human rights, court, judgment, complaint.

\section{Introduction}

This paper explores the statistical and legal analysis of individual applications submitted to the European Court of Human Rights (ECtHR) by citizens of the Baltic States - Estonia, Lithuania and Latvia, in the years 2016-2018. Estonia, Lithuania and Latvia share similar history. They used to be under Soviet dominance as part of the Soviet Union. They joined the Council of Europe at a similar time (Estonia and Lithuania in 1993, Latvia in 1995); they are all members of the EU (since 2004). They are also rec- 
ognized as neo-democracies, which in a special way cares for the system of human rights protection. The paper aims to examine both similarities as well as differences between the Baltic States with regard to violations of the European Convention on Human Rights - the number of applications (admissible and inadmissible or struck out), of violations by article and the judgements.

The paper will verify two hypotheses. Firstly, that the number of individual complaints from the Baltic States is low in comparison with the general number of total applications submitted. The smaller number of applications against Estonia, Lithuania and Latvia results from appropriate implementation of the ECHR by those states into their domestic legal systems. Second, mostly the same articles of the Convention are violated by the Baltic States.

\section{Short remarks on the European Convention of Human Rights (ECHR)}

The Convention on the Protection of Human Rights and Fundamental Freedoms was one of the key documents adopted by the Council of Europe in 1950 and entered into force on September $3^{\text {rd }}$, 1953. The Convention is presently one of a very few international documents effectively regulating human rights protection (Harris, O'Boyle, Bates, Buckley, 2014: 5-6).

Protocols 11 and 14 are integral parts of the current version of the Convention and introduce significant changes to the document. The ECHR consists of three sections. Section I includes a catalogue of fundamental human rights which over time has been supplemented by additional Protocols (Nowicki, 2013: 20). Section II designs and regulates the procedure before the European Court of Human Rights (ECtHR) and the last Section deals with miscellaneous provisions. The European Convention is a document significant in the sense that in addition to the cataloguing of civil and political rights and freedoms, it has its own control system of the international obligations based on a judicial organ - the ECtHR established in 1959 (Garlicki, 2011: 3). It is worth to underline that the Court is empowered to hear individual complaints (applications) (Art. 34 ECHR) and inter-state complaints (cases) (Art. 33 ECHR) ${ }^{1}$. The entry into force of Protocol 11 in 1998 resulted in the implementation of the common right of the applicant to the ECtHR (Balcerzak, 2011: 276). The Committee of Ministers of the Council of Europe supervises the execution of the Court's judgments. Nowadays, the ECtHR guarantees the protection of human rights and not 
just in Western Europe, it also guards the standards of the rule of law in the sphere of human rights in the Eastern European states (Christoffersen, Rask Madesen, 2011: 3).

The ECHR international control system is based on the rightful assumption that the effective protection of human rights should be guaranteed firstly in the domestic legal order and the international protection mechanisms should only play supplementary role. A situation where the international system provides for the protection in the first place is unacceptable, unless the domestic instruments are ineffective or permanently inaccessible (Nowicki, 2000: 193). As a rule, the ECtHR in Strasbourg should only be seen as a last instance resort after the internal procedures before national courts are exhausted (Harris, O'Boyle, Bates, Buckley, 2014: 5-6). The Statute of the Council of Europe lays the grounds for such interpretation in its Art. 3 as well as in the preamble to the ECHR, Interlaken Final Declaration of 2010, Izmir Final Declaration of 2011 and Brighton Final Declaration of 2012.

As a rule, obligations arising from the ECHR are objective in character. It means that the human rights and fundamental freedoms protected in the Convention no longer belong to the exclusive internal competence of particular states (Wrońska, 2012: 515-516). Exclusion of a particular matter from the national competence does not equal the "incapacitation" of the state, only the limitation of its will (imposition of the obligation to consider the international law decisions in the domestic legislation and practice) and submission to the international control in at least minimal level (Mik, 1992: 6).

A specific feature of the ECHR obligations is the fact that, on one hand it is the state that plays the role of the entitled and obliged party, whereas on the other, it is an individual that is an entitled subject as well (Garlicki, 2010: 5). According to Art. 14 in relation with Art. 1 of the ECHR, everyone is entitled to international protection despite nationality (or its lack), sex, race, color, religion, political or other opinion, national or social origin, association with a national minority, property, birth, as long as it falls under the jurisdiction of a state that is party to the ECHR. In such obligations, the state is the obliged party. Such provision constitutes an important element of obligation. In the ECHR it deals with the provision of human rights and fundamental freedoms. Violation of rights and freedoms arising from the ECHR is sanctioned mainly through the ECtHR judgments. 


\section{Complaints to the European Court of Human Rights}

The numerical analysis of the Strasbourg jurisdiction indicates that the number of complaints to the Court, as well as the number of the judgments issued, are increasing successively. The increase results directly from the rising number of member states in the Council of Europe since the beginning of the 1990s (Leach, 2011: 6). Currently there are 47 member states (including Russia and Turkey who have the highest recorded number of complaints submitted to the Court). The ECHR is a law binding to some 800 million citizens of all member states in the Council of Europe (Garlicki, 2010: 167). There were total of $1,315,650$ complaints brought to the Court in the period 2004-2018. There was an even greater number of complaints disallowed access to the court procedure. According to Art. 35 of the Convention, the Court will not deal with applications that do not meet the admissibility criteria (applications that are for example anonymous, deal with matters already examined by the Court or if the domestic remedies have not been exhausted). The number of rejected applications amounts to up to $90 \%$.

Analysis of the subsequent time periods shows the tendency for an increase in the number of complaints submitted, as well as in the number of judgements issued by the Court in Strasbourg, although in the last two years the number has fallen significantly. The peak years were 2010-2012.

Graph 1. Number of complaints submitted to the ECtHR (47 member states) in 2004-2018

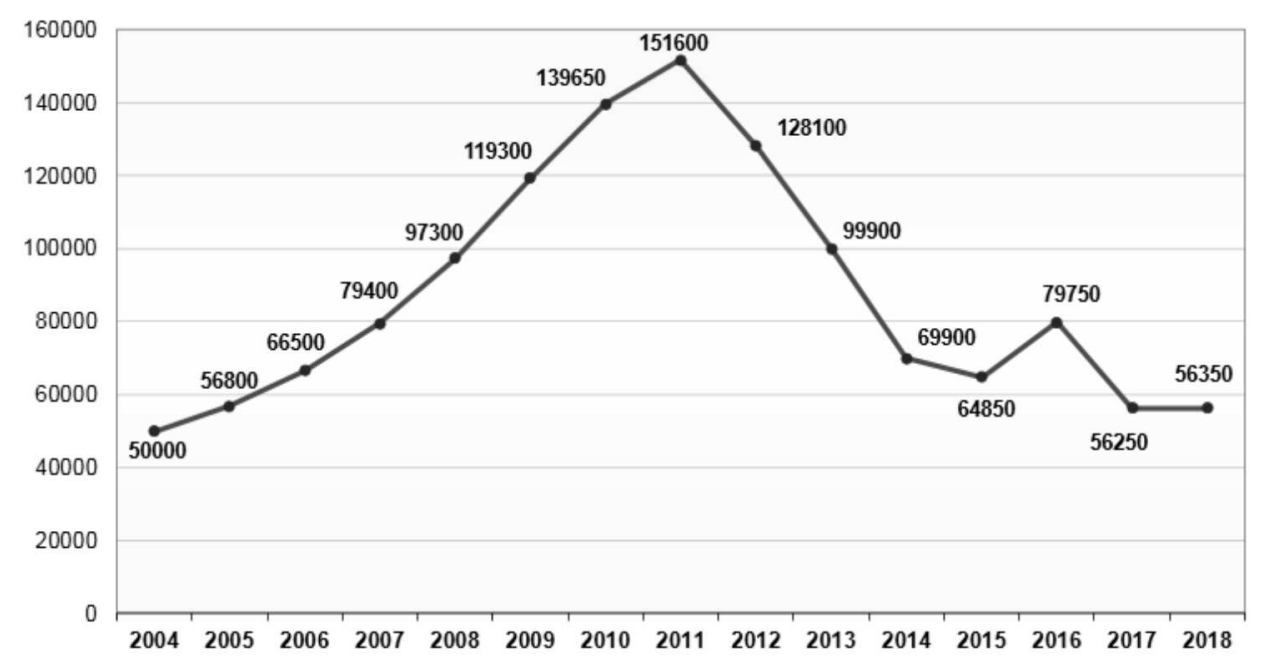

Source: chart prepared based on the information available at the European Court of Human Rights, www.echr.coe.int (visited on 10.07.2019). 
The record number of complaints for a single year $(151,600)$ was reached in 2011 and resulted from the fact that major changes in the procedure were to become effective in 2012. Protocol 11 of 1998, allowed to submit individual applications to the ECtHR (at the same time the European Commission on Human Rights was abolished). On the one hand, such change undoubtedly increased the scope of human rights protection, but on the other it had a negative impact on the ECHR system insofar that the high number of individual applications blocked the functioning of the Court. The EHRC system was not designed to handle the volume of individual complaints emanating from the 47 member states of the Council of Europe (compared to the 22 member states prior to 1989). Paradoxically, the system became a victim of its own success. In order to decrease the flow of complaints, in the reforming process based on the establishments made during the conferences in Interlaken, Izmir and Brighton, various mechanisms were gradually introduced (in the judicature and in the regulations, as well as through the additional Protocols to the Convention).

In 2010 Protocol $14^{2}$ became effective and introduced significant changes to facilitate and to accelerate the procedure before the ECtHR: 1) applications clearly inadmissible can be rejected by the one judge decision (compared to three judge decision previously); 2) an additional admissibility condition was introduced - applications revealing that the complainant did not suffer substantial disadvantage can be rejected; 3) if the substantial matter in the application has been resolved; 4) for any other reason established by the Court, it is no longer justified to continue the examination of the application. Protocol 14 regulations intensified the admissibility criteria for individual applications and eliminated recurring cases which resulted in a decrease in the number of applications after 2011. Protocol 14 proved to be effective in terms of the system's improvement. It also raised doubts of a legal nature - does the reform brought by the Protocol reflects the spirit of the Convention by just simplifying the overloaded Court's procedures, or does it propose a new view of the ECtHR's role? Protocol 14 does not allow everyone to pursue justice in the Strasbourg Court as it limits the chance to those whose rights have been significantly reduced. (Jóźwicki, 2013: 190).

Complaints brought before the ECtHR are complaints that are properly submitted, inadmissible complaints are those not meeting the conditions set forth in the ECHR. Complaints directed to be heard by the ECtHR are characterized by their correctness, validity and proper argumentation of the presented case. They prove the existence of a legal problem in the domestic legal system of the state that has remained unresolved for a long period of time due to the lack of a proper national norm or due to the functioning of an improper regulation. 
Graph 2. Number of applications allocated to the judicial formation (47 member states) between 2004-2018

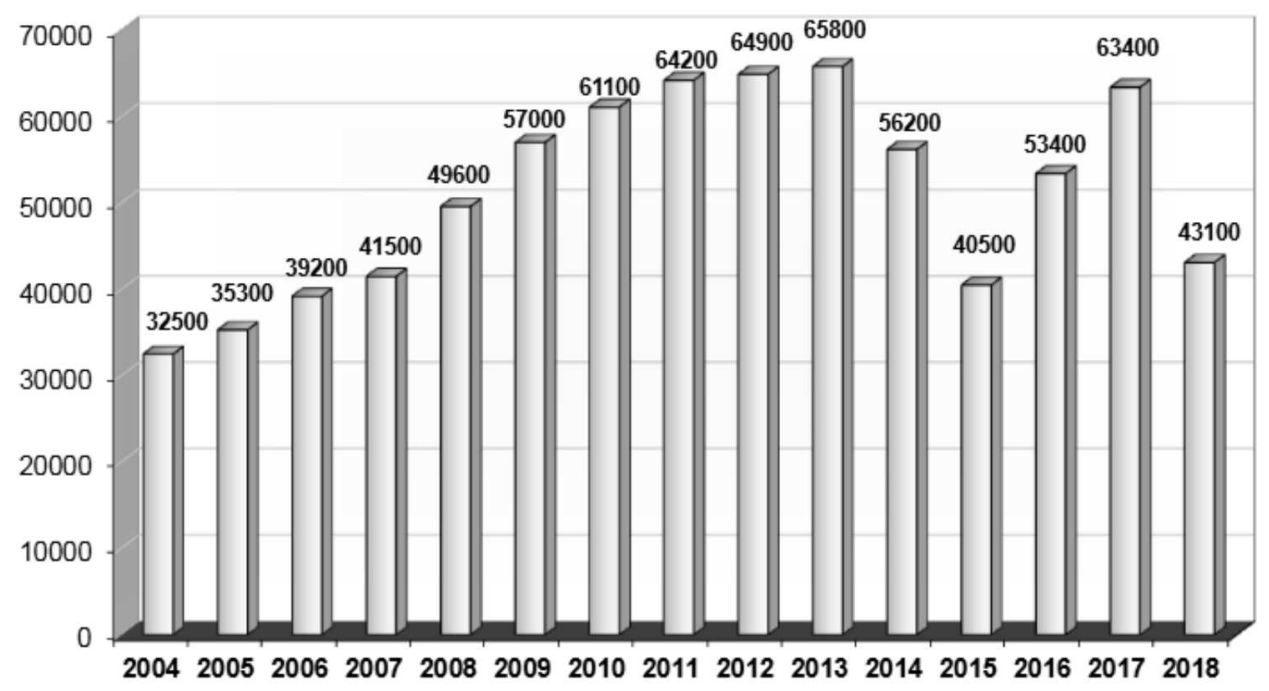

Source: chart prepared based on the information available at The European Court of Human Rights, www.echr.coe.int (visited on 10.07.2015).

\section{Baltic States before the ECtHR}

The number of complaints submitted by individuals from Lithuania, Latvia and Estonia has maintained a stable level and seems modest compared to the total number of complaints submitted from the 47 member states of the Council of Europe as a whole. The number of complaints arising from the Baltic States is low which firstly reflects that they are small countries and secondly, that their domestic laws provide effective procedures to properly secure human rights protection.

Since its establishment in 1959 and up to 2018, the total number of complaints submitted from all member states of the Council of Europe and recognized by the Court with judgment amounted to 21,575 . What is interesting, is that more than half of those complaints came from seven member states: Turkey (3,532), Russia $(2,501)$, Italy $(2,396)$, Romania $(1,434)$, Ukraine $(1,304)$, Poland $(1,166)$ and France $(1,013) .{ }^{3}$ The ECHR provisions mostly infringed were: the right to a fair trial (Art. 6), right to property (Art. 1 of Protocol 1), right to life (Art. 2) and the prohibition of torture and other inhumane treatment (Art. 3). The other rights and freedoms included in the ECHR were violations of much more limited scope. 
Jurisdiction of the European Court of Human Rights in the Baltic...

Graph 3. Processing applications in Estonia 2016, 2017, 2018

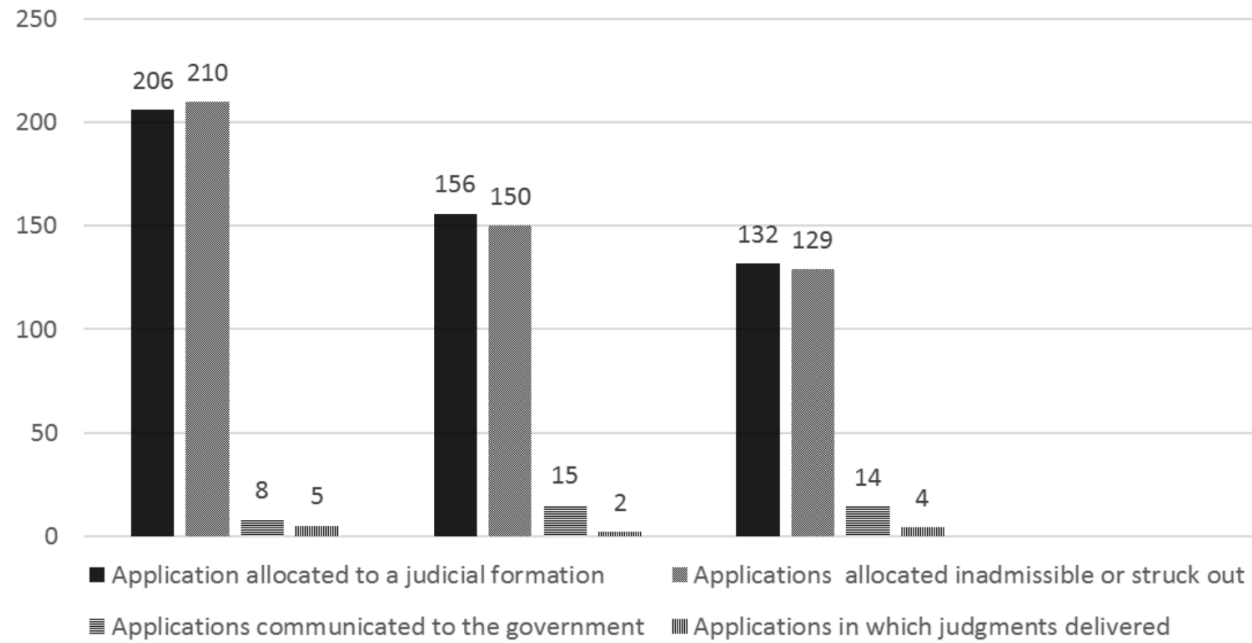

Graph 4. Processing applications in Lithuania in 2016, 2017, 2018



The number of complaints submitted to the ECtHR differs from the number of judgments issued by the Court. The difference results from the long procedure before the Court in Strasbourg (approximately 5 years).

The total number of judgments (1959-2018) in cases originating in the Baltic States is as following: Estonia - 58 (15 judgements finding no violation), Latvia - 140 (40 judgements finding no violation), Lithuania - 140 (40 judgements finding no violation). The total number of judgments is- 
Graph 5. Processing applications in Latvia in 2016, 2017 and 2018

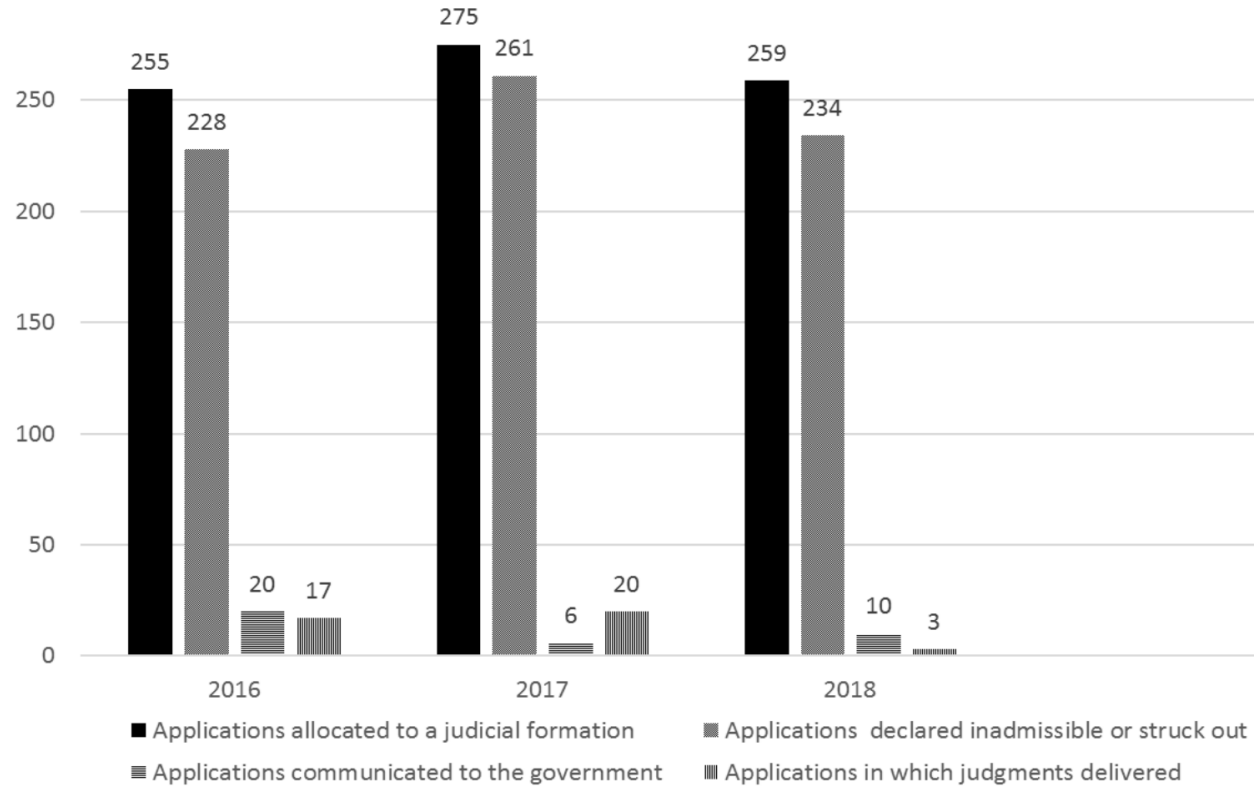

Graph 6. Number of judgements in all 47 member states

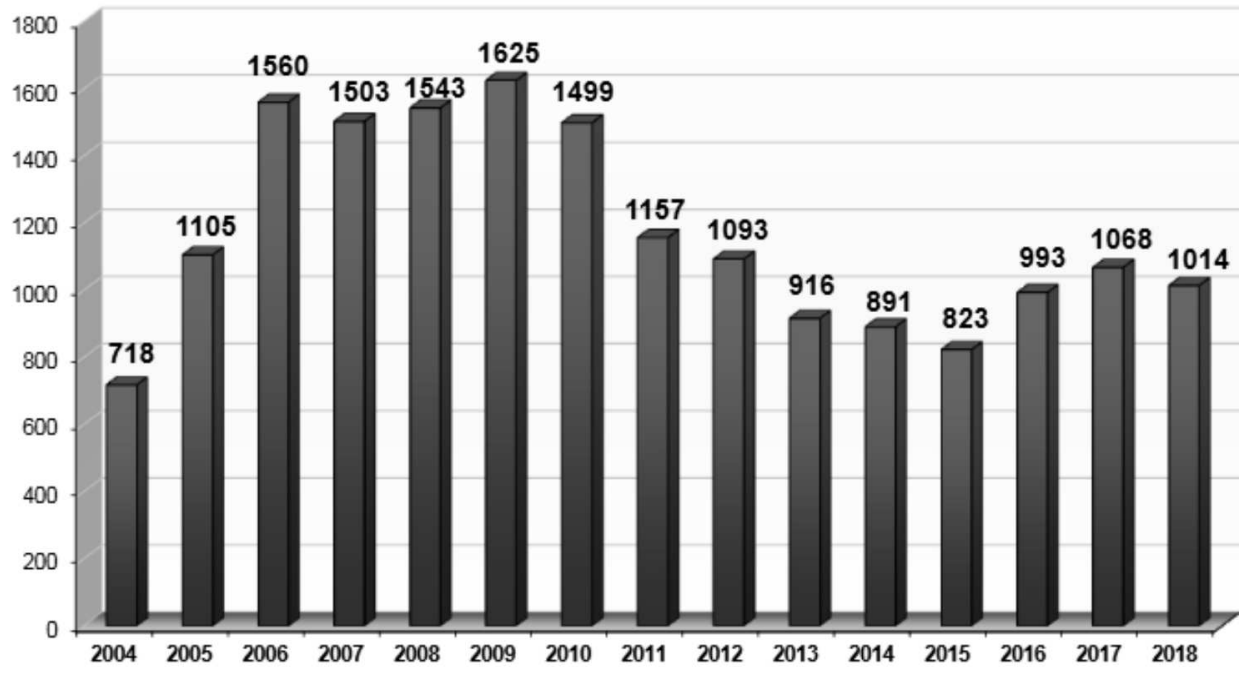

https://www.echr.coe.int/Documents/Stats_analysis_2018_ENG.pdf

Source: chart prepared based on the information available at The European Court of Human Rights, www.echr.coe.int (visited on 10.07.2019). 
sued for the three Baltic States amounted to 329 which represents $1.8 \%$ of the total number of all judgments. Broken down for individual states the statistics show: Estonia $-0.2 \%$, Latvia $-0.6 \%$ and Lithuania $-0.9 \%$ (of all judgments).

Based on the statistical data, the Baltic States are located way below the average level of the Council of Europe's member states violating the Convention. The lowest numbers of judgements issued by the ECtHR from 1959 to 2018, relate to the following states: Monaco (3 judgments), Lichtenstein (9 judgements), Andorra (8 judgments) and San Marino (13 judgements). The relatively small number of judgments reflects the effectiveness of human rights protection systems in these states, but the low population levels involved also influences the statistics. The internal system preliminarily filters all complaints and neutralizes the violations of law conducted by state organs. However, it is legitimate to analyze the judgments in the light of the particular articles of the Convention violated.

Most of the judgments against Baltic States dealt with the violation of Art. 6 of the Convention that is the right to a fair trial, especially in terms of the length of the procedures. In Estonia, 15 out of all 58 judgments addressed the right to a fair trial, including 7 referring directly to the lengthiness of court proceedings. In Latvia, 19 out of 140 judgments dealt with Art. 6 and in Lithuania 29 out of 194 judgements concerned the same problem including 27 directly aiming at the lengthiness of proceedings. It is justified to point the clear domination of such violations. The significantly high number of Art. 6 violations draws the Baltic States into the general trend observed in most of the Council of Europe's member states and reveals the underdeveloped legal system in the matter. Not only new member states such as Poland, Russia and Turkey struggle with the excessive duration of court proceedings and violations of Art. 6. The problem is also clearly visible in countries with long-standing membership in the Council of Europe and with many years of experience in exercising democratic state standards behind them, countries such as France, Austria, Italy and Germany (Hillebretcht 2014: 121-123). The right to have a case handled without undue delay is an important element of the right to a fair trial in the light of the Art. 6 of the ECHR. The right to a fair trial includes the right to have the judgment issued in "reasonable time" (Kłak, 2012: 27).

Article 5 (right to liberty and security) has also been infringed quite often in the Baltic States. 10 judgements based on Art. 5 were issued in the case of Estonia, 24 in Lithuania and 59 in Latvia. Other violations of the Convention were noted incidentally, however, 30 judgments against Lithuania specifically dealt with the protection of property (Protocol 1.1). 
The Court issued interesting judgments where violations of Art. 10 (freedom of expression) were found. In Delfi v. Estonia (Application no. 64569/09) issued in 2015, the ECtHR spoke for the first time about the liability of internet companies for comments posted on-line and it brought controversies. The Court Great Chamber ruled on June 15, 2015 that holding the commercial internet information service liable for anonymous defamatory comments posted online does not constitute violation of Art. 10 of the Convention. The application was brought to the Court by the Estonian company Delfi AS, editor and owner of one of the biggest internet news portals. In the service provided by the company an article had been published dealing with changes to the local ferry carrier schedule. The generally accessible forum located below the text had soon been filled with negative and offensive comments. The comments were removed after six weeks, following intervention by the carrier and the case ended in the civil court which ruled against the internet news company. It was brought before the Court in Strasbourg that such facts provide for violation of Art. 10 of the Convention protecting the right to free expression.

In 2018, in case Sekmadienis Ltd v. Lithuania (Application no. 69317/14) the ECtHR found Lithuania responsible for the violation of Art. 10 of the Convention. The application was brought to the Court by the Lithuanian clothing company which in 2012 had run an advertising campaign themed on Jesus and Mary. The graphical images featured in the campaign graphical images showed two people modelling the company's clothing collection with halos over their heads and with captions reading "Jesus, what trousers!", "Holy Mother, what a dress!" and "Jesus Mary, what are you wearing?!". The campaign offended the religious community and the Lithuanian office for consumer protection punished the company with a fine for the "inappropriate use of Jesus and Mary features in the advertising posts" which led to "lack of respect for the religion with the violation of public morality". The company argued in Strasbourg that it was a violation of its right to free expression protected by Art. 10 of the Convention. The Court ruled in favour of the applicant and confirmed such violation.

\section{Conclusions}

In light of the presented data, Estonia, Lithuania and Latvia actively participate in the process of building proper guarantees for human rights protection. The relatively low number of judgments handed down in the years analyzed, as well as between 1990s and 2018, against the Baltic States, 
proves the effective system of national law protecting human rights. It should be noted that mostly the same articles of the Convention are violated by the Baltic States. Considering that individual application can be brought to the Court only after the domestic procedures are exhausted and the number of judgments issued in Baltic cases (less than $1 \%$ in each of the three states compared to the total numbers of judgments from all member states), it can be argued that the Estonian, Latvian and Lithuanian legal systems are tight in the field of human rights protection. It cannot be argued that the citizens of these states do not follow legal solutions offered by the European Convention on Human Rights.

\section{$\mathrm{N} \mathrm{O} \mathrm{T} \mathrm{E} \mathrm{S}$}

1 The article further examines only individual applications therefore the terms "complaint", "case" and "application" will be used when referring to complaints brought to the ECtHR by individuals.

2 Protocol no. 14 to the Convention for the Protection of Human Rights and Fundamental Freedoms amending the control system of the Convention CETS 194 (13.05.2004).

3 http://www.echr.coe.int/Documents/Overview_19592014_ENG.pdf (accessed on 12.07.2019).

\section{R E F E R E N C E S}

Anagnostou D., 2013. The European Court of Human Rights: Implementing Strasbourg's Judgments on Domestic Policy, Edinburgh University Press.

Application no. 64569/09 (Delfi v. Estonia)

Application no. 69317/14 (Sekmadienis Ltd v. Lithuania)

Balcerzak M., 2011. Prace międzyrzadowe nad dtugookresowa reforma Europejskiego Trybunatu Praw Człowieka w latach 2009-2011, (in:) M. Balcerzak, T. Jasudowicz, J. Kapelańska-Pręgowska (eds.), Europejska konwencja praw człowieka $i$ jej system kontrolny - perspektywa systemowa $i$ orzecznicza, Toruń.

Bates E., 2010. The Evolution of the European Convention on Human Right: from its Inception to the Creation of the Permanent Court of Human Rights, Oxford University Press.

Brighton Declaration on 19-20.04.2012, http://www.echr.coe.int/Documents/2012_ Brighton_FinalDeclaration_ENG.pdf

Christoffersen J., Rask Madesen M., 2011. Introduction: The European Court of Human Rights between Law and Politics, (in:) J. Christoffersen, M. Rask Madesen, The European Court of Human Rights between Law and Politics, Oxford University Press. 
Derlatka M., 2009, Skarga konstytucyjna w Niemczech, Warszawa.

European Convention on Human Rights 1950 (Convention for the Protection of Human Rights and Fundamental Freedoms) Konwencja o Ochronie Praw Człowieka i Podstawowych Wolności sporządzona w Rzymie dnia 4 listopada 1950 r., zmieniona następnie Protokołami nr 3, 5 i 8 oraz uzupełniona Protokołem nr 2 (OJ 1993 No. 61, poz. 284).

Forowicz M., 2000. The Reception of International Law in the European Court of Human Rights, Oxford University Press.

Garlicki L. (ed.), 2010. Konwencja o Ochronie Praw Człowieka i Podstawowych Wolności, vol. I, Warszawa.

Garlicki L. (ed.), 2011. Konwencja o Ochronie Praw Człowieka i Podstawowych Wolności, Tom II, Warszawa.

Garlicki L., 2010. Nowe demokracje przed Europejskim Trybunatem Praw Cztowieka, (in:) J. Jaskiernia (ed.), Rada Europy a przemiany demokratyczne w państwach Europy Środkowej $i$ Wschodniej w latach 1989-2009, Toruń.

Harris D., O'Boyle M., Bates E., Buckley C., 2014. Law of the European Convention on Human Rights, Oxford University Press.

Hart J.W., 2010. The European Human Rights System, Law Library Journal, vol. 102 , no. 4.

Hillebretcht C., 2014. Domestic Politics and International Human Rights Tribunals: The Problem of Compliance, Cambridge University Press.

Interlaken Declaration on 19.02.2010, http://www.echr.coe.int/Documents/2010_ Interlaken_FinalDeclaration_ENG.pdf

Izmir Declaration on the Futire of the European Court of Human Rights 2627.04.2011, http://www.echr.coe.int/Documents/2011_Izmir_FinalDeclarati on_ENG.pdf

Jóźwicki W., 2013. Europejski Trybunał Praw Człowieka a dobro wspólne, (in:) W. Arndt, F. Longhamps de Berier, K. Szczucki (red.), Dobro wspólne. Teoria i praktyka, Warszawa.

Jóźwicki W., 2015. Protocol 16 to the ECHR: A Convenient Tool for Judicial Dialogue and Better Domestic Implementation of the Convention? (in:) E. Kużelewska, D. Kloza, I. Kraśnicka, F. Strzyczkowski (eds.), European judicial System as a Challenge for Democracy, Intersentia Cambridge.

Kłak P. Cz., 2012. Pojęcie skutecznego środka odwotawczego w odniesieniu do przewlekłości postępowania w rozumieniu art. 13 EKPC a polska skarga na przewlektość postępowania karnego, (in:) Hereditas Mercaturae: ksiega pamiatkowa dedykowana świętej pamięci profesorowi Stanisławowi Miklaszewskiemu, Kraków.

Leach P., 2011. Taking a case to the European Court of Human Rights, Oxford University Press.

Mik C., 1992. Charakter, struktura i zakres zobowiązań z Europejskiej Konwencji Praw Człowieka, Państwo i Prawo, no. 4. 
Nowicki M. A., 2000. Nowe standardy Konwencji dotyczace krajowej ochrony podstawowych praw, (in:) Zasady procesu karnego wobec wyzwań wspótczesności. Ksiega ku czci prof. Stanistawa Waltosia, Warszawa.

Nowicki M. A., 2013. Europejski Trybunał Praw Człowieka. Wybór orzeczeń, Warszawa.

Nowicki M. A., 2013. Wokól Konwencji Europejskiej. Komentarz do Europejskiej Konwencji Praw Człowieka, Warszawa.

Protocol no. 14 to the Convention for the Protection of Human Rights and Fundamental Freedoms, Amending the Control System of the Convention, 13 May 2004, Council of Europe Treaty Series no. 194.

Uerpmann R., Konstytucyjne funkcje Europejskiej Konwencji Praw Człowieka (http://epub.uni-regensburg.de/22429/1/Uerpmann_ECHR_Wroclaw.pdf)

Violations by Article and by State, http://www.echr.coe.int/Documents/Overview_ 19592014_ENG.pdf

Violations by Article and by State, http://www.echr.coe.int/Documents/Stats_vio lation_1959_2014_ENG.pdf

Wrońska I., 2015. The policy of development and suport for human rights protection by the Visgrad Group states from the 10-year EU membership perspective, (in:) A. Piekutowska, I. Wrońska (eds.), Ten years of the Visegrad Group member states in the European Union, Warszawa-Białystok.

Wrońska I., 2012. Polska przed Europejskim Trybunałem Praw Człowieka w latach 2000-2010 - analiza statystyczna, prawna i faktyczna, (in:) R. Sztychmiler, J. Krzywkowska (eds.), Problemy z sadowa ochrona praw człowieka, vol. II, Olsztyn. 